\title{
ANALISIS AKUNTANSI PERKOPERASIAN TERHADAP PERNYATAAN STANDAR AKUNTANSI KEUANGAN NOMOR 27 PADA PERKOPERASIAN UNIT DESA KARYA JAYA KIJANG
}

\author{
Rachmad Chartady \\ (Dosen STIE Pembangunan Tanjungpinang) \\ chartady@stie-pembangunan.ac.id
}

\begin{abstract}
Abstrak: Permasalahan yang hendak dicari jawabannya dalam penelitian adalah bagaimana penerapan Pernyataan Standar Akuntansi Keuangan Nomor 27 tentang Akuntansi Perkoperasian di Koperasi Unit Desa Karya Jaya Kijang dan apakah penerapannya telah sesuai dengan Pernyataan Standar Akuntansi Keuangan Nomor 27.Sejalan dengan masalah tersebut penelitian ini dilaksanakan dengan menggunakan metode Deskriptif Kualitatif. Dalam penelitian ini subjek penelitian ditentukan menurut kebutuhan dan kepentingan penelitian untuk mendapatkan atau memperoleh data dari sumber yang dapat dipercaya kebenarannya.Untuk selanjutnya dari aspek penelitian ini akan diperoleh data dengan cara wawancara yang mendalam baik terhadap individu pengambi keputusan dan para pengurus Koperasi Unit Desa Karya Jaya Kijang.Analisis data untuk penelitian dengan pendekatan kualitatif yang diawali dengan pengumpulan data yang dilakukan dengan pengamatan, wawancara, dokumentasi dan penarikan kesimpulan pada tahap akhir.Hasil analisis menunjukan bahwa secara umum Koperasi Unit Desa Karya Jaya Kijang telah menerapkan PSAK Nomor 27 tentang Akuntansi Perkoperasian dengan baik. Hal ini dapat dilihat dari beberapa hal, seperti pada pengakuan pendapatan dan beban koperasi, walaupun belum menyajikan semua laporan keuangan secara terpisah.Penerapan PSAK Nomor 27 tentang Akuntansi Perkoperasian pada Koperasi Unit Desa Karya Jaya Kijang telah sesuai dengan PSAK Nomor 27, tetapi ada hal - hal yang belum sesuai dengan PSAK Nomor 27 seperti pada penyajian pendapatan dan beban koperasi. Koperasi Unit Desa Karya Jaya Kijang tidak memisahkan pendapatan dari transaksi dengan anggota dan non anggota.
\end{abstract}

Kata Kunci: Penerapan Standar Akuntansi Keuangan Nomor 27 Tentang Akuntansi Perkoperasian, Koperasi.

\section{PENDAHULUAN}

Pada era globalisasi saat ini setiap perusahaan maupun koperasi sangat penting untuk menjaga kelangsungan hidup usahanya dalam menghadapi persaingan dan tantangan dunia bisnis. Koperasi di Indonesia memiliki landasan hukum dengan diakuinya koperasi sebagai salah satu bentuk organisasi yang turut aktif dalam perekonomian rakyat.Menurut undang-undang nomor 25 tahun 1992 pasal 1 ayat 1 tentang perkoperasian, menyebutkan bahwa koperasi Indonesia merupakan badan usaha yang beranggotakan perorangan atau badan hukum dengan melandaskan kegiatannya berdasarkan prinsip koperasi, sekaligus sebagai gerakan ekonomi rakyat berdasarkan asas kekeluargaan.

Koperasi mempunyai peranan yang sangat besar dalam pelaksanaan pembangunan nasional di Indonesia. Koperasi sebagai sarana peningkatan kemajuan ekonomi, yaitu bagi anggota koperasi maupun masyarakat. Hal ini sesuai dengan tujuan koperasi yaitu memajukan kesejahteraan anggotanya khususnya dan masyarakat pada umumnya. Koperasi sebagai lembaga ekonomi yang mengedepankan profit motive dan diharapkan dapat bertindak sebagai lembaga pemenuhan kebutuhan anggotanya. Apabila profit motive sebagai acuan bagi koperasi, maka kedudukan Sisa Hasil Usaha (SHU) tidak ada bedanya dengan laba dilembaga usaha lainnya.

Koperasi mempunyai peranan dan kedudukan yang sama dengan badan usaha lainnya dalam pembangunan, khususnya pada sektor ekonomi. Koperasi sebagai pelaku ekonomi diharapkan dapat berkembang secara sehat dan kuat sejajar dengan badan usaha lainnya.

Koperasi membutuhkan jasa akuntansi untuk mengelola data keuangan guna menghasilkan informasi keuangan sebagai dasar pengambilan keputusan ekonomi maupun untuk meningkatkan mutu dalam pengelolaan usahanya. 
Setiap akhir tahun buku diselenggarakan Rapat Anggota Tahunan untuk memantau perkembangan kinerja koperasi sebagai wujud pertanggung jawaban atas kinerja koperasi selama satu periode tertentu.

Pengurus bertangggung jawab dan wajib melaporkan kepada Rapat Anggota tentang segala sesuatu yang menyangkut tata kehidupan koperasi. Laporan keuangan merupakan bagian dari laporan pertanggung jawaban pengurus tentang tata kehidupan koperasi.

Koperasi Unit Desa Karya Jaya Kijang merupakan sebuah badan usaha yang bergerak dibidang perkoperasian yang memiliki beberapa unit usaha dan sebagai salah satu koperasi yang mendapatkan bantuan dana APBD Propinsi Kepulauan Riau. Beberapa unit usaha koperasi ini tidak terlepas dari peran para anggota koperasi pada khususnya dan peran non anggota koperasi pada umumnya.

Dalam laporan keuangan pada Koperasi Unit Desa Karya Jaya Kijang belum menggambarkan adanya pemisahan pendapat yang timbul akibat transaksi dengan anggota dan non anggota dan juga belum memisahkan antara beban anggota dan non anggota.

Setiap akhir tahun seluruh anggota koperasi akan menerima Sisa Hasil Usaha berdasarkan perhitungan hasil usaha. Berkaitan dengan itu, pendapatan usaha pada tahun 2008-2009 sebesar Rp 152.933.730 dan Rp 141.512.018 yang menunjukan pendapatan usaha dari anggota, padahal jumlah pendapatan tersebut secara keseluruhan bukan berasal dari anggota namun berasal dari non anggota.

Pada dasarnya, pendapatan koperasi berasal dari transaksi non anggota yang diakui sebagai pendapatan dan dilaporkan terpisah dari pendapatan anggota dalam laporan keuangan perhitungan hasil usaha sebesar nilai transaksi. Pada hakekatnya SHU yang dibagi kepada anggota bersumber dari anggota sendiri sedangkan SHU yang berasal dari non anggota pada dasarkan tidak dibagikan kepada anggota melainkan dijadikan sebagai cadangan koperasi.

Pada umunya laporan keuangan Koperasi Unit Desa Karya Jaya Kijang belum melakukan pemisahan pendapatan dan beban sehubungan dengan transaksi koperasi anggota dan non anggota sehingga sepenuhnya belum tergambar perlakuan akuntansi yang sesuai dengan Pernyataan Standar Akuntansi Keuangan (PSAK) Nomor 27.

Berdasarkan uraian diatas, Penerapan Standar Akuntansi Keuangan No.27 dirasakan sangat penting karena mampu membantu Koperasi Unit Desa Karya Jaya Kijang dalam melakukan menganalisa laporan keuangan terhadap perkoperasian.

\section{METODE PENELITIAN \\ Jenis Penelitian}

Metode Penelitian yang digunakan yaitu metode penelitian deskriptif kuantitatif. Penelitian terhadap Koperasi Unit Desa Karya Jaya Kijang menekankan pada kebenaran dan realitas fakta untuk menghindari adanya teori atau opini yang membingungkan. Penelitian ini mengenai perhitungan sisa hasil usaha yang berdasarkan Pernyataan Standar Akuntansi Keuangan (PSAK) No.27 pada Koperasi Unit Desa Karya Jaya Kijang.

\section{Teknik Pengumpulan Data}

Data yang diperlukan dalam penelitian ini berkenaan dengan laporan keuangan koperasi khususnya Pengakuan dan Beban Usaha beserta perhitungan Sisa Hasil Usaha. Sumber penelitian data menggunakan data sekunder yaitu dimana sumber data penelitian yang diperoleh peneliti secara tidak langsung atau melalui perantara.

Metode Pengumpulan Data yang digunakan yaitu :

a. Dokumentasi

b. Wawancara

c. Observasi

d. Penelitian Kepustakaan

\section{Populasi dan Sampel}

Subjeck dalam penelitian ini ditentukan menurut kebutuhan dan kepentingan penelitian untuk memperoleh data dari sumber yang dapat dipercaya kebenarannya. Aspek penelitian ini diperoleh data dengan cara wawancara yang mendalam baik terhadap individu pengambilan keputusan, dan para pengurus Koperasi Unit Desa Karya Jaya Kijang.

\section{Batasan Operasional Variabel}

Variabel yang digunakan dalam penelitian ini yaitu penerapan Pernyataan Standar Akuntansi Keuangan (PSAK) No.27 yang nantinya responden akan diminta untuk memberikan jawaban mengenai Penerapan Standar 
Akuntansi Keuangan yang berkaitan dengan laporan sisa hasil usaha dan beban koperasi.

\section{Teknik Pengolahan Data}

a. Menyusun data-data yang diperlukan yang berhubungan dengan judul penelitian yang akan penulis teliti.

b. Menyesuaikan Perhitungan Sisa Hasil Usaha dengan pendapatan dan beban anggota dan non anggota, serta menerapkan perlakuan akuntansi koperasi sesuai dengan Pernyataan Standar Akuntansi Keuangan (PSAK) No.27

c. Memberikan rekomendasi dan saran-saran kepada pihak Koperasi Unit Desa Karya Jaya Kijang yang berkenaan dengan hasil dari penelitian ini.

\section{Teknik Analisa Data}

Penerapan metode kualitatif pada penelitian ini adalah untuk mengungkapkan kebenaran dengan berlandaskan atas teori yang berlaku umum.Proses analisis diawali dengan pengumpulan data. Tahap terakhir yaitu dengan menarik kesimpulan dan hasil kesimpulan perlu diverifikasi ulang agar dapat mengembangkan ketelitian hasil penelitian dan selanjutnya memberikan saran dan rekomendasi kepada pihak koperasi untuk beberapa hal yang dianggap perlu agar laporan keuangan koperasi.

\section{HASIL DAN PEMBAHASAN}

Penelitian ini diawali dengan pencarian dan penyusunan data yang diperlukan dapat dijelaskan sebagai berikut :

\section{Penerapan Pernyataan Standar Akutansi Keuangan No.27 tentang Akuntansi Perkoperasian atau Sisa Hasil Usaha di Koperasi Unit Desa Karya Jaya Kijang}

a. Perhitungan Hasil Usaha Berdasarkan Pernyataan Standar Akuntansi Keuangan (PSAK) No.27

Perhitungan hasil usaha harus memuat hasil usaha dengan anggota dan laba atau rugi kotor dengan non anggota. Perhitungan hasil usaha menyajikan informasi mengenai pendapat dan beban-beban usaha dan beban perkoperasian selama priode tertentu yang disebut sisa hasil usaha.

Sisa hasil usaha yang diperoleh mencangkup hasil usaha dengan anggota dan laba atau rugi kotor dan non anggota.Konsekuensinya koperasi sebagai milik anggota yang harus memberikan manfaat, dapat berupa harga yang lebih menguntungkan, kualitas yang lebih baik, dan tepat jumlah.

\section{Koperasi xxx}

Perhitungan Hasil Usaha

31Desember 20xx

\begin{tabular}{|c|c|}
\hline Partisipasi Anggota & \\
\hline Partisipasi Bruto Anggota & $\mathrm{xxxx}$ \\
\hline Beban Pokok & $(\mathrm{xxx})$ \\
\hline Partisipasi Neto Anggota & $\mathrm{xxxx}$ \\
\hline \multicolumn{2}{|l|}{ Pendapatan dari Non Anggota } \\
\hline Penjualan & $\mathrm{xxxx}$ \\
\hline Harga Pokok & $(\mathrm{xxx})$ \\
\hline $\begin{array}{l}\text { Laba / Rugi Kotor dengan Non } \\
\text { Anggota }\end{array}$ & $\mathrm{xxXX}$ \\
\hline Sisa Hasil Usaha Kotor & $\mathrm{xxxx}$ \\
\hline \multicolumn{2}{|l|}{ Beban Operasi } \\
\hline Beban Usaha & $(\mathrm{xxx})$ \\
\hline SHU koperasi & $\mathrm{xxxx}$ \\
\hline Beban Perkoperasian & $(\mathrm{xxx})$ \\
\hline $\begin{array}{ccc}\begin{array}{c}\text { SHU } \\
\text { perkoperasian }\end{array} & \text { setelah beban } & \\
\end{array}$ & $\mathrm{xxxx}$ \\
\hline Pendapatan dan beban lain - lain & $\operatorname{xxxx}$ \\
\hline $\begin{array}{l}\text { SHU sebelum pos - pos luar } \\
\text { biasa }\end{array}$ & $\operatorname{xxxx}$ \\
\hline Pendapatan dan beban luar biasa & $\operatorname{xxxx}$ \\
\hline SHU sebelum pajak & $\mathrm{xxxx}$ \\
\hline Pajak penghasilan & $(\mathrm{xxx})$ \\
\hline SHU setelah pajak & $\operatorname{xxxx}$ \\
\hline
\end{tabular}

Koperasi yang memberikan jasa selain kepada anggota yaitu non anggota wajib menggambarkan adanya partisipasi pendapatan non anggota dengan tujuan agar tidak terjadi kesalahan dalam hal pembagian sisa hasil usaha.

b. Sisa Hasil Usaha Berdasarkan Pernyataan Standar Akuntansi Keuangan Nomor 27

Untuk melihat perhitungan SHU berikut dipaparkan berdasarkan jenis koperasi.

1) SHU Koperasi Penjualan

Dalam koperasi partisipasi bruto anggota adalah harga jual produk koperasi ke pasar. Dapat dijabarkan sebagai berikut :

\section{$P K=H j k x Q j k$}

Dimana :

PK : Pendapatan Koperasi

Hjk : Harga Jual Koperasi

Ojk : Jumlah Produk yang di Jual

2) SHU Koperasi Pembelian 
Hasil penjualan koperasi adalah sama dengan partisipasi bruto anggota dan sama dengan pendapatan koperasi dari nilai belanja yang dilakukan oleh anggota kepada koperasi.

Perhitungannya adalah :

\section{$P K=H j k a x Q b a$}

Keterangan:

PK : Pendapatan Koperasi

Hjka : Harga barang yang dibeli oleh anggota dari koperasi

Qba : Jumlah barang yang dibeli oleh anggota dari koperasi

Perhitungan sisa hasil usaha koperasi menurut PSAK No 27. Dapat diilustrasikan secara matematis sebagai berikut :

1. $\mathrm{PbA}=\mathrm{BpA}+\mathrm{PnA}$

2. $\mathrm{SpA}=\operatorname{PnA}-(\mathrm{Bu}+\mathrm{Bk})$

$\mathrm{SHU}=\mathrm{SPA}+\mathrm{p}$

$\mathrm{SHU}=(\mathrm{PbA}-\mathrm{BPA})+\mathrm{p}-\mathrm{BU}+\mathrm{Bk}$

3. $\mathrm{PnA}=\mathrm{PbA}-\mathrm{BPA}$

$\mathrm{SPA}=\mathrm{PnA}-(\mathrm{BU}+\mathrm{BK})$

$\mathrm{p}=\mathrm{PjNA}-\mathrm{BNA}$

4. $\mathrm{SHU}=[(\mathrm{PBA}-\mathrm{BPA})-(\mathrm{BU}+$ $\mathrm{Bk})$ ]

$$
+[(\text { PNA - BNA })]
$$

Keterangan :

SHU = Sisa Hasil Usaha

SPA = Sisa Partisipasi Anggota (transaksi dengan anggota )

$\mathrm{P}=$ Laba (transaksi dengan anggota)

PBA = Partisipasi Bruto Anggota

BPA = Beban Pokok Anggota

BU = Beban Usaha Koperasi

$\mathrm{BK}=$ Beban Perkoperasian

PnA = Partisipasi Neto Anggota

PjNA = Penjualan kepada Non Anggota

BNA $=$ Beban Non Anggota

c. Proses pembuatan laporan perhitungan hasil usaha (SHU) anggota pada Koperasi Unit Desa Karya Jaya Kijang

Sisa hasil usaha berdasarkan anggaran dasar dan anggaran rumah tangga adalah pendapatan yang diperoleh dalan satu tahun buku dikurangi dengan biaya yang dapat dipertanggung jawabkan, penyusunan dan kewajiban lainnya termasuk pajak dalam tahun buku yang bersangkutan.

Berdasarkan hasil wawancara yang telah dilakukan kepada bagian keuangan Koperasi Unit Desa Karya Jaya Kijang menyatakan bahwa perhitungan hasil usaha menyajikan informasi mengenai pendapatan dan beban koperasi pada periode tertentu yang menghasilkan sisa hasil usaha. Sisa hasil usaha ini diperoleh dari hasil usaha dari anggota, laba atau rugi kotor dengan non anggota.

Perhitungan hasil usaha ini mengingat manfaat dari usaha Koperasi Unit Desa Karya Jaya Kijang yang tidak semata-mata diukur dari sisa hasil usaha atau laba, tetapi lebih ditentukan pada manfaat bagi anggota.

Berikut disajikan laporan saldo perhitungan hasil usaha pada Koperasi Unit Desa Karya Jaya Kijang untuk tahun 2008-2009.

Tabel 1 : Hasil Perhitungan Hasil Usaha

\begin{tabular}{|c|c|}
\hline Tahun & Saldo \\
\hline 2008 & $\operatorname{Rp~51.443.851~}$ \\
\hline 2009 & $\operatorname{Rp~53.991.627~}$ \\
\hline
\end{tabular}

Dari keterangan diatas maka diperoleh jumlah sisa hasil usaha sebelum pajak pada tahun 2008 sebesar Rp 51.443.851, dan tahun 2009 sebesar Rp 53.991.627.

Jumlah sisa hasil usaha tersebut berdasarkan rapat anggota ditahun 2009 akan dialokasikan pada beberapa bagian yang sebagai berikut :

\begin{tabular}{|c|l|c|c|}
\hline & & $\mathbf{2 0 0 9}$ & $\mathbf{2 0 0 8}$ \\
\hline 1 & Cadangan & $50 \%$ & $40 \%$ \\
\hline 2 & $\begin{array}{l}\text { SHU Bagian } \\
\text { Anggota }\end{array}$ & $30 \%$ & $30 \%$ \\
\hline 3 & Dana Pengurus & $5 \%$ & $10 \%$ \\
\hline 4 & Dana Karyawan & $5 \%$ & $10 \%$ \\
\hline 5 & $\begin{array}{l}\text { Dana } \\
\text { Pendidikan }\end{array}$ & $5 \%$ & $5 \%$ \\
\hline 6 & Dana Sosial & $2,5 \%$ & $2,5 \%$ \\
\hline 7 & $\begin{array}{l}\text { Dana } \\
\text { Pembangunan }\end{array}$ & $2,5 \%$ & $2,5 \%$ \\
\hline
\end{tabular}

Dibawah ini akan disajikan perhitungan hasil sisa usaha yang telah dibuat oleh Koperasi Unit Desa Karya Jaya Kijang tahun 2009

a. Perhitungan SHU tahun 2009 Rp 53.991.627

b. Pembagian SHU koperasi Unit Desa Karya Jaya Kijang sesuai dengan kesepakatan

\begin{tabular}{|l|l|l|c|}
\hline 1 & Cadangan & $:$ & $50 \% \times 53.991 .627=$ \\
& & & $26.995 .813,50$ \\
\hline 2 & SHU Anggota & $:$ & $\begin{array}{c}30 \% \times 53.991 .627= \\
16.197 .488,10\end{array}$ \\
\hline
\end{tabular}




\begin{tabular}{|c|l|l|c|}
\hline \multirow{2}{*}{3} & Dana Pengurus & $:$ & $\begin{array}{c}5 \% \times 53.991 .627= \\
2.699 .581,35\end{array}$ \\
\hline \multirow{2}{*}{4} & $\begin{array}{l}\text { Dana } \\
\text { Karyawan }\end{array}$ & $:$ & $\begin{array}{c}5 \% \times 53.991 .627= \\
2.699 .581,35\end{array}$ \\
\hline \multirow{2}{*}{5} & $\begin{array}{l}\text { Dana } \\
\text { Pendidikan }\end{array}$ & $:$ & $\begin{array}{c}5 \% \times 53.991 .627= \\
2.699 .581,35\end{array}$ \\
\hline \multirow{2}{*}{6} & Dana Sosial & $:$ & $\begin{array}{c}2,5 \% \times 53.991 .627= \\
1.349 .790,68\end{array}$ \\
\hline \multirow{2}{*}{7} & Dana & $:$ & $\begin{array}{c}2,5 \% \times 53.991 .627= \\
1.349 .790,68\end{array}$ \\
& Pembangunan & $:$ & \multicolumn{2}{|c|}{} \\
\hline
\end{tabular}

Pembagian SHU seperti yang di atas tidak menggambarkan adanya partisipasi bruto dari non anggota dari perhitungan sisa hasil usahanya juga belum terlihat efisien, karena partisipasi anggota dan non anggota dijadikan satu dalam hal penerimaan pendapat koperasi.

Sehingga anggota koperasi juga menikmati sisa hasil usaha atas partisipasi non anggota.

Sebaiknya agar dapat menggambarkan adanya partisipasi bruto antara anggota dan non anggota, diluar dari penetapan atau pengalokasian dana sisa hasil usaha, setelah mendapatkan jumlah sisa hasil usaha koperasi terlebih dahulu menetapkan sumber SHU koperasi antara jumlah partisipasi bruto anggota dan non anggota seperti yang tergambar dibawah ini :

$\begin{array}{ll}\text { SHU Tahun } 2009 & \text { : Rp 53.991.627 } \\ \text { Sumber SHU koperasi } & \\ \text { Transaksi anggota } & \text { : Rp 40.000.000 } \\ \text { Transaksi non anggota } & \text { : Rp } 13.991 .627\end{array}$

Pembagian SHU Koperasi Unit Desa Karya Jaya Kijang sesuai dengan kesepakatan

\begin{tabular}{|c|c|c|c|}
\hline 1 & Cadangan & : & $\begin{array}{l}50 \% \times 40.000 .000= \\
20.000 .000\end{array}$ \\
\hline 2 & SHU Anggota & $:$ & $\begin{array}{l}30 \% \times 40.000 .000= \\
12.000 .000\end{array}$ \\
\hline 3 & $\begin{array}{l}\text { Dan } \\
\text { Pen }\end{array}$ & : & 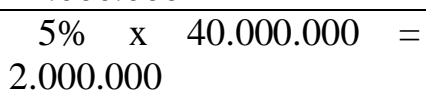 \\
\hline 4 & $\begin{array}{l}\text { Dana } \\
\text { Karyawan }\end{array}$ & : & $\begin{array}{c}5 \% \times 40.000 .000= \\
2.000 .000\end{array}$ \\
\hline 5 & $\begin{array}{l}\text { Dana } \\
\text { Pendidikan }\end{array}$ & & 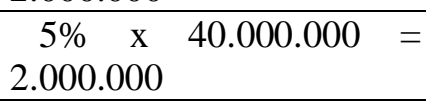 \\
\hline 6 & Dana Sosial & : & $\begin{array}{l}2,5 \% \mathrm{x} \quad 40.000 .000= \\
1.000 .000\end{array}$ \\
\hline 7 & $\begin{array}{l}\text { Dana } \\
\text { Pembangunan }\end{array}$ & & $\begin{array}{lcc}2,5 \% & \mathrm{x} & 40.000 .000 \\
1.000 .000 & \end{array}$ \\
\hline
\end{tabular}

Sumber SHU dari non anggota sebesar Rp 13.991.627 boleh ditetapkan perusahaan sebagai cadangan koperasi untuk pengembangan usaha atau dilakukan pembagian sisa hasil usaha kepada para anggota dengan asumsi dan ketentuan kas atau modal yang diperoleh koperasi mampu menutupi keuangan perusahaan tahun berjalan.

Penerapan Akuntansi Koperasi sesuai dengan Pernyataan Standar Akuntansi Keuangan (PSAK) No. 27 atas pendapatan dan beban koperasi pada Koperasi Unit Desa Karya Jaya Kijang

a. Pendapatan Koperasi menurut Pernyataan Standar Akuntansi Keuangan (PSAK) No. 27

Pendapatan koperasi atau partisipasi bruto pada dasarnya adalah penjualan barang atau jasa kepada anggota.

Pendapatan koperasi yang berasal dari transaksi dengan non anggota diakui sebgai pendapatan (penjualan) dan dilaporkan terpisah dari partisipasi anggota dalam laporan perhitungan hasil usaha sebesar nilai transaksi.

Pendapatan pada perhitungan hasil usaha hasil koperasi terhadap beberapa karakteristik sebagai berikut :

* Pendapatan yang timbul dari transaksi penjualan produk atau penyerahan jasa kepada anggota dan non anggota

— Pendapatan tertentu yang realilasi penerimaannya masih tergantung pada persyaratan atau ketentuan yang ditetapkan

b. Beban usaha dan beban perkoperasian menurut Penyataan Standar Akuntansi Keuangan (PSAK) No.27

Demi meningkatkan kesejahteraan anggota koperasi maka harus menjalankan kemampuan sumber daya anggota, baik secara khusus maupun sumber daya koperasi secara nasional.

Beberapa karakteristik beban pokkok penjualan dan beban pada koperasi sebagai berikut :

* Beban pokok penjualan produk kepada anggota dan non anggota

* Beban yang terjadi karena aktivitas koperasi dalam kaitannya dengan program pemerintah

* Beban yang pada hakekatnya dapat dipisahkan menjadi beban untuk kegiatan pelayanan kepada anggota dan non anggota

c. Penyajian Pendapatan Koperasi dan Beban Perkoperasian Pada Koperasi Unit Desa Karya Jaya Kijang 
Pada Koperasi Unit Desa Karya Jaya Kijang pendapatn atas penjualan barang selama periode akutansi.

Jumlah pendapatan atas penjualan barang diperoleh oleh koperasi atas dasar penjualan tunai kepada anggota dan non anggota.

Dalam pelaporannya pendapatan yang diterima koperasi tersebut tidak memisahkan nilai penjualan barang antara anggota dan non anggota serta dibuat dalam satu unsur pelaporan dalam satu laporan keuangan perkoperasian.

Tabel 2

Jumlah Penjualan Barang Kepada Anggota

\begin{tabular}{|l|c|c|}
\hline \multicolumn{1}{|c|}{ Keterangan } & $\mathbf{2 0 0 8}$ & $\mathbf{2 0 0 9}$ \\
\hline Penjualan Jasa & $\mathrm{Rp}$ & $\mathrm{Rp}$ \\
Telkom & 54.729 .250 & 30.368 .950 \\
\hline Penjualan & $\mathrm{Rp}$ & $\mathrm{Rp}$ \\
Beban Kos & 3.449 .500 & 3.770 .500 \\
\hline Jumlah & $\mathrm{Rp}$ & $\mathrm{Rp}$ \\
& 58.178 .750 & 34.139 .450 \\
\hline
\end{tabular}

Koperasi Unit Desa Karya Jaya Kijang juga memberikan beberapa pelayanan jasa sebagai berikut :

Jumlah Pendapatan Jasa Kepada Anggota tahun 2008 - 2009

\begin{tabular}{|c|c|c|}
\hline Keterangan & 2008 & 2009 \\
\hline $\begin{array}{l}\text { Jasa Simpan } \\
\text { Pinjam }\end{array}$ & $\begin{array}{l}\mathrm{Rp} \\
1.000 .000\end{array}$ & $\begin{array}{l}\mathrm{Rp} \\
11.000 .000\end{array}$ \\
\hline $\begin{array}{l}\text { Jasa Tagihan } \\
\text { Listrik }\end{array}$ & $\begin{array}{l}\mathrm{Rp} \\
4.629 .900\end{array}$ & $\begin{array}{l}\mathrm{Rp} \\
11.208 .650\end{array}$ \\
\hline $\begin{array}{l}\text { Penjualan } \\
\text { Tiket }\end{array}$ & $\begin{array}{l}\mathrm{Rp} \\
1.369 .600\end{array}$ & $\begin{array}{l}\mathrm{Rp} \\
1.321 .000\end{array}$ \\
\hline Jasa Informasi & $\begin{array}{l}\mathrm{Rp} \\
446.950\end{array}$ & $\begin{array}{l}\mathrm{Rp} \\
441.750\end{array}$ \\
\hline Sewa Gedung & $\begin{array}{l}\text { Rp } \\
50.000 .000\end{array}$ & $\begin{array}{l}\mathrm{Rp} \\
52.400 .000\end{array}$ \\
\hline $\begin{array}{l}\text { Penjualan } \\
\text { Tiket LN }\end{array}$ & $\begin{array}{l}\mathrm{Rp} \\
1.348 .000\end{array}$ & $\begin{array}{l}\mathrm{Rp} \\
563.500\end{array}$ \\
\hline S/P Swamitra & $\begin{array}{l}\text { Rp } \\
64.638 .293\end{array}$ & $\begin{array}{l}\mathrm{Rp} \\
45.929 .204\end{array}$ \\
\hline Jumlah & $\begin{array}{l}\mathrm{Rp} \\
123.452 .743\end{array}$ & $\begin{array}{l}\mathrm{Rp} \\
122.864 .104\end{array}$ \\
\hline
\end{tabular}

\section{Pembahasan}

Dalam koperasi ada unsur ekonomi dan unsur sosial. Unsur ekonomi karena koperasi harus menghasilkan produk untuk dijual pada masyarakat sebagai penghasilan koperasi dan biaya untuk memperoleh dan menjual produk tersebut harus dikelola secara efisien.

Unsur sosial karena sebagai kumpulan orang koperasi bertujuan meningkatkan kesejahteraan anggotanya dengan perbedaan prinsip koperasi maka berbeda juga elemen keuangan yang ada dalam koperasi.

Laba rugi dicatat pada saat dihasilkan dan beban dicatat ketika terjadi penyajian perhitungan hasil usaha Koperasi Unit Desa Karya Jaya Kijang tidak membedakan pendapat antara dari anggota dan non anggota.

\section{PENUTUP}

\section{Simpulan}

Secara umum Koperasi Unit Desa Karya Jaya Kijang telah menerapkan PSAK No. 27 tentang Akuntansi Perkoperasian dengan baik. Hal ini dapat dilihat dari beberapa hal seperti pada pengakuan pendapat dan beban koperasi, walaupun belum menyajikan semua laporan keuangan secara terpisah.

Penerapan PSAK No. 27 tentang Akuntansi Perkoperasian pada Koperasi Unit Desa Karya Jaya Kijang telah sesuai dengan PSAK No. 27 seperti adanya penyajian pendapatan dan beban koperasi. Koperasi Unit Desa Karya Jaya Kijang tidak memisahkan pendapat dari transaksi dengan anggota dan non anggota.

\section{Saran}

Berdasarkan hasil penelitian yang telah dilakukan pada Koperasi Unit Desa Karya Jaya Kijang, maka disarankan :

1. Sebaiknya Koperasi Unit Desa Karya Jaya Kijang dalam membuat laporan perhitungan hasil usaha melakukan pemisahan antara pendapatan dan beban koperasi antara anggota dan non anggota. Pada pembagian sisa hasil usaha sebaiknya koperasi melakukan pemisahan penyajian perkiraan transaksi non anggota dan anggota selanjutnya melakukan pembagian SHU sebesar partisipasi anggota dan sebaiknya dicadangkan untuk memenuhi kebutuhan koperasi dimasa yang akan datang.

2. Sebaiknya Koperasi Unit Desa Karya Jaya Kijang dalam hal penyajian pendapat dan beban koperasi juga melakukan pemisahan antara transaksi anggota dan non anggota agar dapat memudahkan pembuat laporan keuangan dan pembaca laporan keuangan mengenai gambaran partisipasi anggota selama priode berjalan. 


\section{DAFTAR PUSTAKA}

Arifin Sitio, Halomoan Tamba, KoperasiTeori dan Praktek, Erlangga, Jakarta, 2001.

Dewi Roseeha, Sukses menulis proposal skripsi, Keen Books, Jakarta, 2010.

Idrus, Muhammad, Metode Penelitian Ilmu Ilmu Sosial, UUI Press, Yogyakarta, 2007.

Ikatan Akuntan Indonesia ( IAI ),Pernyataan Standar Akuntansi Keuangan, Salemba Empat, Jakarta, 2002

Indriantoro, Nur dan Supomo, Bambang, Metodelogi Penelitian Bisnis, BPFE, Yogyakarta, 2002.

Rakhmawati Patriatiningrum, Penelitian Analisis Penerapan PSAK NO. 27 tentang Akuntansi Koperasi dan Pengaruhnya terhadap perkembangan usaha pada KUD di Kabupaten Kendal Tahun 2004 - 2005, Semarang, 2007.

Salim, Agus, Teori dan Paradigma Ilmu Sosial, Edisi Kedua, Tiara Wacana, Yogyakarta, 2006.

Samsuri, Marsyaf, Mata Kuliah Seminar Akuntansi Materi. Akuntansi Biaya Pinjaman Dan Perkoperasian Fakultas / Jurusan Ekonomi / Akuntansi, Universitas Mercu Buana, Jakarta, 2008.

Sito, Arifin. Tamba, Halomoan, Koperasi teori dan praktek, Erlangga, Jakarta, 2001.

Subiyanto ibnu, Metodologi Penelitian

Manajemen dan Akuntansi, UPP AMP YKPN, Yogyakarta, 2000.

Suwardjono, Teori Akuntansi, BPFE, Yogyakarta, 2005.

Sekretariat Jendral dan Kepaniteraan

Mahkamah Konstitusi Republik Indonesia, Undang - Undang Dasar Negara Republik Indonesia Tahun 1945, Mahkamah Konstitusi Republik Indonesia, Jakarta, 2009.

Umar, Husein, Riset Akuntansi, PT.

Gramedia Pustaka Utama, Jakarta, 2003. Undang-undang Nomor 25 Tahun 1992 tentang Perkoperasian. 